\title{
Effect of thermoresistant protease of Pseudomonas fluorescens on rennet coagulation properties and proteolysis of milk
}

\author{
Lizandra F. Paludetti, ${ }^{1,2} \odot$ Alan L. Kelly, ${ }^{2}$ () and David Gleeson ${ }^{1 *}$ () \\ ${ }^{1}$ Teagasc, Animal and Grassland Research and Innovation Centre, Moorepark, Fermoy, County Cork P61 C996, Ireland \\ ${ }^{2}$ School of Food and Nutritional Sciences, University College Cork, County Cork T12 K8AF, Ireland
}

\begin{abstract}
This study aimed to investigate the effect of different activity levels of a thermoresistant protease, produced by Pseudomonas fluorescens (ATCC 17556), on the cheesemaking properties of milk and proteolysis levels. Sterilized reconstituted skim milk powder was inoculated with the bacteria, and after incubation, centrifuged to obtain a supernatant-containing protease. Raw milk was collected and inoculated to obtain a protease activity of $0.15,0.60$, and $1.5 \mathrm{U} / \mathrm{L}$ of milk (treatments $\mathrm{P} 1, \mathrm{P} 4$, and $\mathrm{P} 10$, respectively). One sample was not inoculated (control) and noninoculated supernatant was added to a fifth sample to be used as a negative control. Samples were stored at $4^{\circ} \mathrm{C}$ for $72 \mathrm{~h}$. After 0,48 , and $72 \mathrm{~h}$, the rennet coagulation properties and proteolysis levels were assessed. The protease produced was thermoresistant, as no significant differences were observed in the activity in the pasteurized $\left(72^{\circ} \mathrm{C}\right.$ for $\left.15 \mathrm{~s}\right)$ and nonpasteurized supernatants. The chromatograms and electrophoretograms indicated that the protease preferably hydrolyzed $\kappa$-casein and $\beta$-casein, and levels of proteolysis increased with added protease activity over storage time. The hydrolysis of $\alpha_{S^{-}}$caseins and major whey proteins increased considerably in P10 milk samples. At $0 \mathrm{~h}$, the increase in the level of protease activity decreased the rennet coagulation time (RCT, min) of the samples, possibly due to synergistic proteolysis of $\kappa$-casein into para- $\kappa$-casein. However, over prolonged storage, hydrolysis of $\beta$-casein and $\alpha_{S^{-}}$casein increased in $\mathrm{P} 4$ and $\mathrm{P} 10$ samples. The RCT of P4 samples increased over time and the coagulum became softer, whereas P10 samples did not coagulate after $48 \mathrm{~h}$ of storage. In contrast, the RCT of P1 samples decreased over time and a firmer coagulum was obtained, possibly due to a lower rate of hydrolysis of $\beta$-casein and $\alpha_{S}$-casein. Increased levels of protease
\end{abstract}

Received October 21, 2019.

Accepted December 26, 2019

*Corresponding author: David.Gleeson@teagasc.ie could result in further hydrolysis of caseins, affecting the processability of milk over storage time.

Key words: psychrotrophic bacteria, milk storage, rennet coagulation property, thermoresistant protease

\section{INTRODUCTION}

The storage of raw milk for extended periods at low temperatures $\left(2\right.$ to $\left.6^{\circ} \mathrm{C}\right)$ on-farm has a significant effect on milk microflora, which becomes mostly composed of gram-positive and gram-negative psychrotrophic bacteria (Lafarge et al., 2004). Increased levels of psychrotrophs in raw milk could negatively affect the manufacture of dairy products, as those bacteria have the ability to produce heat-resistant extracellular proteases and lipases. Those enzymes can survive thermal treatments, such as pasteurization (e.g., $72^{\circ} \mathrm{C}$ for 15 s) or even UHT processing $\left(138^{\circ} \mathrm{C}\right.$ for $2 \mathrm{~s}$ or $149^{\circ} \mathrm{C}$ for $10 \mathrm{~s}$ ), decreasing yield and sensory quality of dairy products during storage (Cousin, 1982; López-Fandiño et al., 1993). Muir (1996) suggested that raw milk with a psychrotrophic count higher than $5 \times 10^{6} \mathrm{cfu} / \mathrm{mL}$ should be rejected for processing, due to the possible high levels of lipases and proteases. The most common psychrotrophs found in raw milk during cold storage belong to the genus Pseudomonas spp., which secrete most of the heat-resistant peptidases during milk cold storage (Ercolini et al., 2009; Baur et al., 2015).

During the late exponential or early stationary growth phase, Pseudomonas bacteria produce thermoresistant alkaline metalloproteases (AprX), generally at a bacterial count of $10^{7}$ to $10^{8} \mathrm{cfu} / \mathrm{mL}$ (Stoeckel et al., 2016). These metalloproteases preferably hydrolyze $\kappa-\mathrm{CN}$, then $\beta-\mathrm{CN}$, and then $\alpha_{\mathrm{S1}^{-}} \mathrm{CN}$, and their activities are optimal at a $\mathrm{pH}$ between 7 and 9 , in a temperature range between 30 and $45^{\circ} \mathrm{C}$ (Decimo et al., 2014; Martins et al., 2015). Zhang et al. (2018) reported that increasing concentrations of AprX resulted in increasing hydrolysis, mainly of $\kappa$-CN, and gelation in UHT milk. Bagliniere et al. (2013) inoculated $0.2 \mathrm{mg} / \mathrm{L}$ of purified AprX into milk and observed increased proteolysis of caseins over storage and destabilization of the 
UHT milk produced after $8 \mathrm{~d}$ of storage. In the case of cheese manufacture, the activity of bacterial proteases can affect the casein content, which may result in low yield, off-flavor (i.e., bitterness), and texture problems (Cousin, 1982; Fox et al., 2017). Mankai et al. (2012) observed a low DM content in Gouda cheeses produced from milk stored at $4^{\circ} \mathrm{C}$ for 48,72 , and $96 \mathrm{~h}$ and related this to the activity of psychrotrophic proteases leading to losses of protein in whey. Boulares et al. (2011) also associated decreased cheese yield with enzymes produced by gram-negative psychrotrophs. High levels of proteolysis can negatively affect cheese manufacture and sensory characteristics of the final product; however, in contrast, certain levels of proteolysis are necessary during cheese ripening. Proteolysis is essential in most cheese varieties, as it is responsible for textural changes (i.e., hardness, elasticity, cohesiveness) and development of flavor during cheese ripening (Fox et al., 2017).

Some studies have correlated psychrotrophic bacterial counts with proteolysis levels in milk, highlighting the negative effect levels higher than $10^{6} \mathrm{cfu} / \mathrm{mL}$ can have on cheesemaking properties of milk (clotting time, curd yield) and cheese sensory characteristics (Leitner et al., 2008; Ricciardi et al., 2015). However, psychrotrophs can produce a range of thermoresistant enzymes, which can be active in different conditions (e.g., temperature, $\mathrm{pH})$. Therefore, in addition to psychrotrophic counts, further studies are necessary to understand the activity and effect of different levels of proteases produced by psychrotrophs on the quality of milk used for cheese production. Those investigations could aid in elucidating to what extent those proteases could have a positive or negative effect on cheese manufacture. Therefore, the objective of this study was to investigate the effect of different activity levels of a thermoresistant protease, produced by a Pseudomonas strain, on the cheesemaking properties and proteolysis of milk.

\section{MATERIALS AND METHODS}

\section{Experimental Design}

The experimental design of this study is shown in Figure 1. Fresh raw milk was collected during milking from the milk line, inoculated with different levels of protease (control, negative control, $0.15,0.60$, and 1.50 $\mathrm{U} / \mathrm{L}$ ), and stored at $4^{\circ} \mathrm{C}$ for $72 \mathrm{~h}$. After 0,48 , and $72 \mathrm{~h}$, rennet coagulation properties and proteolysis levels in the samples were assessed. After transfer of supernatant containing the protease (time $0 \mathrm{~h}$ ), milk samples were immediately prepared (pasteurized and $\mathrm{pH}$ adjusted) and the rennet coagulation properties were assessed. A maximum of 30 min elapsed between inoculation and assessment of properties. The experiment was repeated in triplicate over a 3 -wk period.

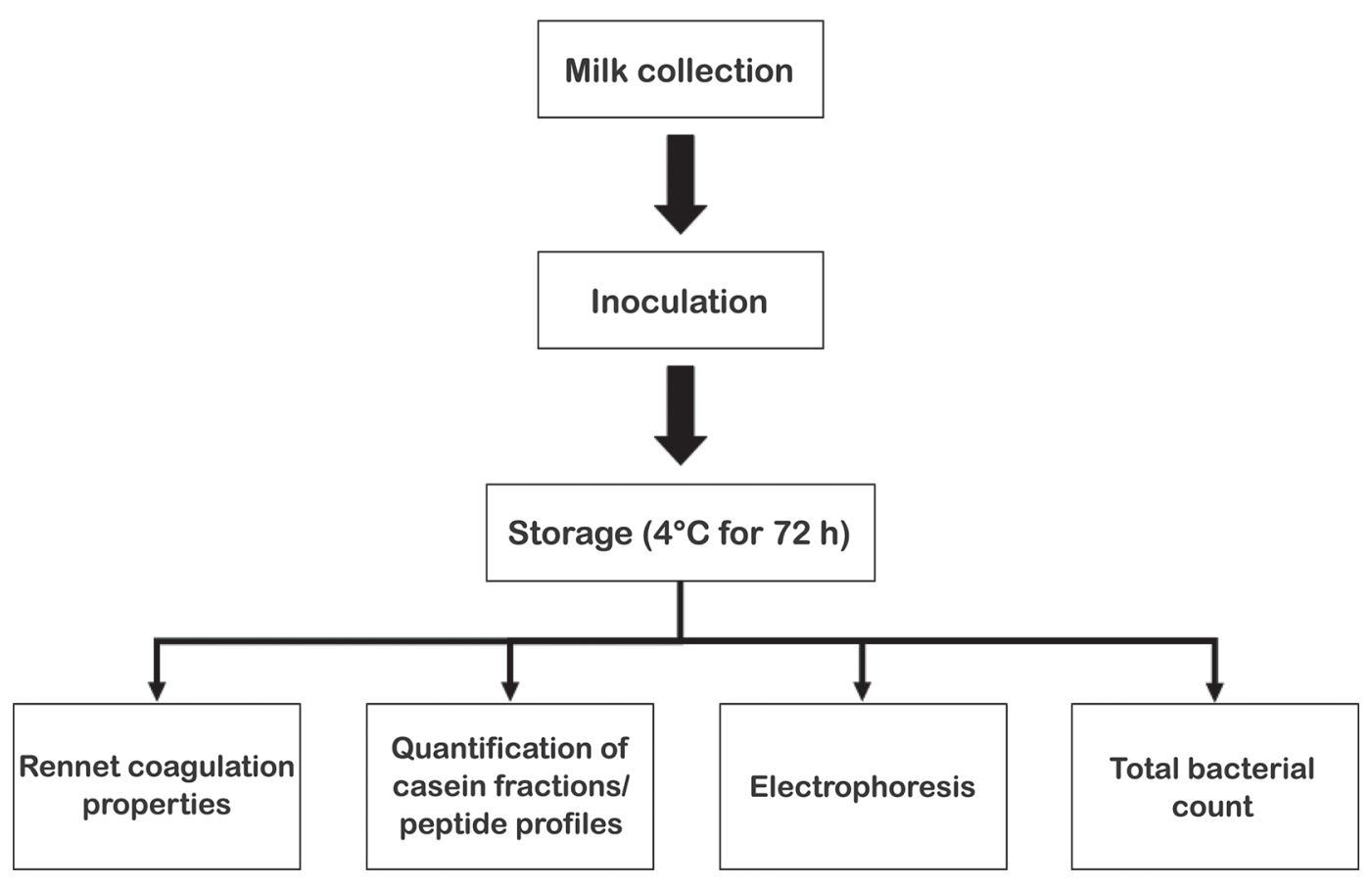

Figure 1. Experimental design: raw milk samples containing different levels of protease activity $(0.15,0.60$, and $150 \mathrm{U} / \mathrm{L})$ were stored at $4^{\circ} \mathrm{C}$ and rennet coagulation properties and proteolysis were assessed after 0,48 , and $72 \mathrm{~h}$. 


\section{Culture of Pseudomonas fluorescens and Protease Extraction}

Pseudomonas fluorescens (ATCC 17556) was grown in nutrient broth (meat extract $3 \mathrm{~g} / \mathrm{L}$, meat peptone 5 $\mathrm{g} / \mathrm{L}$; Sigma Aldrich, Dublin, Ireland) for $48 \mathrm{~h}$ at $26^{\circ} \mathrm{C}$ with stirring at $90 \mathrm{rpm}$. Afterward, $1 \mathrm{~mL}$ of the inoculated nutrient broth was spread-plated on blood agar plates (horse blood agar, $7 \%$ concentration, base No. 2, Oxoid, Basingstoke, UK) and plates were incubated for $24 \mathrm{~h}$ at $26^{\circ} \mathrm{C}$. Bacterial colonies were transferred to $100 \mathrm{~mL}$ of sterilized reconstituted skim milk powder (RSMP; 10\% wt/vol). The inoculated RSMP bottles were incubated for $120 \mathrm{~h}$ at $10^{\circ} \mathrm{C}$ with stirring at 90 rpm. Afterward, RSMP was centrifuged at 20,000 $\times g$ at ambient temperature for $30 \mathrm{~min}$ and the supernatant containing protease was collected.

\section{Azocasein Assay}

The production of protease by the strain was verified using azocasein (Sigma Aldrich, Dublin, Ireland) as substrate, as described by Andreani et al. (2016). The results were used to determine the activity of the protease. One unit of protease activity was defined as the required amount of enzyme able to hydrolyze azocasein to give an increase of 1 unit of absorbance per milliliter of sample (supernatant) per minute (Leighton et al., 1973). The following equation was used for calculations:

$$
\begin{aligned}
& \text { Proteolytic activity }\left(\mathrm{U} \cdot \mathrm{mL}^{-1} \cdot \mathrm{min}^{-1}\right)= \\
& \frac{\left(\mathrm{ABS}_{\text {sample }}-\mathrm{ABS}_{\mathrm{neg}}-\mathrm{ABS}_{\text {blank }}\right) \times 10 \times F_{d}}{t},
\end{aligned}
$$

where $\mathrm{ABS}_{\text {sample }}, \mathrm{ABS}_{\text {neg }}$, and $\mathrm{ABS}_{\text {blank }}=$ absorbance of the sample, negative control, and blank, respectively; $F_{d}$ $=$ factor of dilution, which is equal to 1.00 as samples were not diluted; and $t=$ time of reaction. In addition, samples of the same supernatant were separated in 2 groups to determine if the protease would still be active; after pasteurization, 1 group of 3 samples was heated to $72^{\circ} \mathrm{C}$ for $15 \mathrm{~s}$, whereas the other 3 samples were not pasteurized. Afterward, those samples were analyzed using the azocasein assay for comparison.

\section{Milk Collection and Inoculation}

At the Teagasc Animal and Grassland Research and Innovation Centre (Moorepark, Cork, Ireland), springcalving cows were milked in a 30-unit side-by-side milking parlor, with milking commencing at $0700 \mathrm{~h}$. The milking equipment used, udder preparation, and sanitation of equipment were as described by Palu- detti et al. (2018). Over 3 wk, raw milk was collected once weekly and transferred directly from the milking machine milk line to $5 \times 500 \mathrm{~mL}$ sterilized bottles. Milk was transported to the Milk Quality Laboratory (Teagasc, Moorepark, Cork, Ireland) in cooling boxes.

Milk samples were inoculated based on the protease activity determined using the azocasein assay (0.030 $\pm 0.006 \mathrm{U} / \mathrm{mL} \cdot \mathrm{min})$. The temperature of the samples was approximately $10^{\circ} \mathrm{C}$ at inoculation. Samples were inoculated with 5,20 , and $50 \mathrm{~mL}$ of supernatant containing protease per L of milk, corresponding to 0.15 , 0.60 , and $1.50 \mathrm{U} / \mathrm{L}$ of milk (treatments P1, P4, and $\mathbf{P 1 0}$, respectively). One milk sample was not inoculated to be used as control (CON), whereas 1 sample of milk was inoculated with $50 \mathrm{~mL}$ of supernatant from RSMP that was not inoculated with $P$. fluorescens and was used as the negative control sample (P10 neg). All milk samples were stored at $4^{\circ} \mathrm{C}$ for up to $72 \mathrm{~h}$.

\section{Total Bacterial Count}

After 0, 48, and $72 \mathrm{~h}$, milk samples from each treatment were tested in duplicate for total bacterial count (TBC). The analysis was performed according to the Standard Methods for the Examination of Dairy Products (Wehr and Frank, 2004). The TBC was estimated using Petrifilm aerobic count plates, a ready-to-use medium (3M, Technopath, Tipperary, Ireland). Samples were incubated for $48 \mathrm{~h}$ at $32^{\circ} \mathrm{C}$ (Laird et al., 2004).

\section{Rennet Coagulation Properties}

The rennet coagulation properties of the inoculated milk were assessed using a Formagraph instrument (model 11700, Foss Electric, Hillerød, Denmark) after 0,48 , and $72 \mathrm{~h}$ of storage. Before analysis, milk samples were treated in a manner that mimicked the procedures applied during the manufacture of Cheddar cheese. Therefore, before adding rennet, samples were subjected to a heat treatment, mimicking industrial processing conditions. After inoculation, samples were placed in a water bath at $72^{\circ} \mathrm{C}$ and temperature was monitored using a thermometer. Samples were maintained in the water bath for $15 \mathrm{~s}$ after their temperature reached $72^{\circ} \mathrm{C}$ (approximately $5 \mathrm{~min}$ ). Immediately after this time, samples were transferred to a water bath at $32^{\circ} \mathrm{C}$, which is the usual temperature of milk at the start of Cheddar cheese manufacture. The $\mathrm{pH}$ of the samples was measured and, when necessary, adjusted to 6.55 with $4 \%$ (vol/vol) lactic acid solution. The milk volumes were renneted with chymosin (1:20 vol/vol dilution of double-strength Chy-max, Pfizer Inc., Milwaukee, WI) at a rate of $36 \mu \mathrm{L} / 10 \mathrm{~mL}$, incubated at $32^{\circ} \mathrm{C}$, and the coagulation properties monitored over a 30 -min period. 


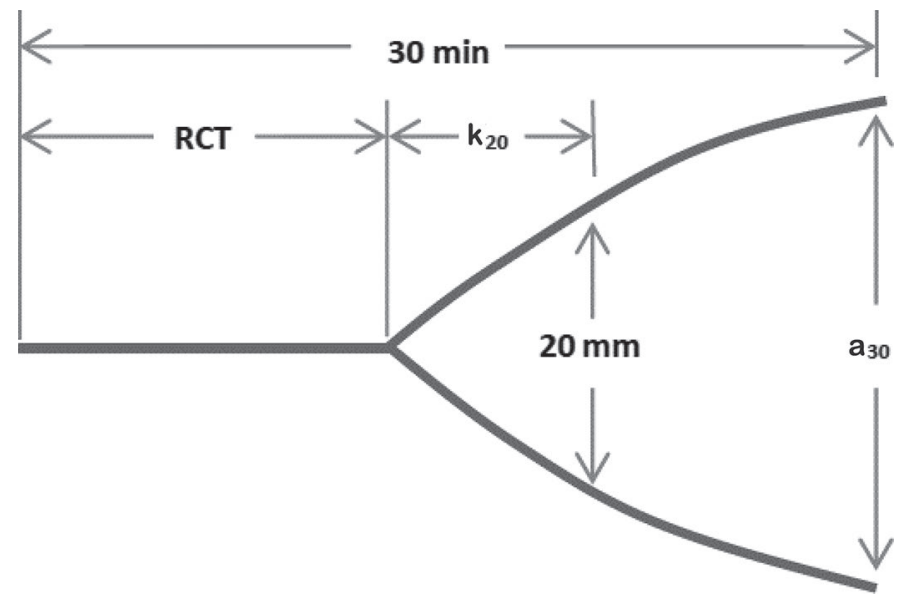

Figure 2. Schematic presentation of milk coagulation properties rennet coagulation time (RCT), curd-firming time $\left(\mathrm{k}_{20}\right)$, and curd firmness at $30 \mathrm{~min}\left(\mathrm{a}_{30}\right)$ ] measured by lactodynamography (McMahon and Brown, 1982).

The properties measured were rennet coagulation time (RCT, min), curd firmness at $30 \mathrm{~min}\left(\mathbf{a}_{\mathbf{3 0}}, \mathbf{m m}\right)$, and curd-firming time $\left(\mathbf{k}_{\mathbf{2 0}}, \mathrm{min}\right)$. Rennet coagulation time is the time from the addition of rennet until the viscosity of milk starts changing (coagulation), $\mathrm{k}_{20}$ is the time from end point of RCT until a curd firmness of 20 $\mathrm{mm}$ is reached, and $\mathrm{a}_{30}$ is the firmness of curd in $\mathrm{mm}$ reached $30 \mathrm{~min}$ after the addition of rennet (McMahon and Brown, 1982; Figure 2).

\section{Quantification of Casein Fractions}

The casein fractions $\left(\kappa-\mathrm{CN}, \alpha_{\mathrm{S}^{-}} \mathrm{CN}, \alpha_{\mathrm{S} 2}-\mathrm{CN}, \beta-\mathrm{CN}\right.$, $\alpha$-LA, $\beta$-LG A, $\beta$-LG B, and total casein) were identified and quantified (in duplicate) in the inoculated milk samples by HPLC. Milk samples $(200 \mu \mathrm{L})$ were diluted in $3,780 \mu \mathrm{L}$ of dissociating buffer $(7 M$ urea and 20 $\mathrm{m} M$ Bis-Tris propane, $\mathrm{pH}$ 7.5). Twenty microliters of mercaptoethanol were added to the diluted samples, after which they were filtered through $0.22-\mu \mathrm{m}$ filters. The equipment used was an Agilent 1200s system (Agilent Technologies, Santa Clara, CA) with a quaternary pump and a multiwavelength detector. The casein fractions were separated in the reversed-phase mode using an Agilent Poroshell 300SB C18 column (2.1 mm $\times$ $7.5 \mathrm{~mm}$; Agilent Technologies). The gradient elution and peak detection were performed according to the method of Mounsey and O'Kennedy (2009).

\section{Peptide Profiles}

The peptide profiles of milk samples collected after 0 , 48 , and $72 \mathrm{~h}$ were obtained by HPLC. The nonprotein fractions of the milk samples were extracted using tri- chloroacetic acid, according to the procedure described in IDF method 20-4 (IDF, 2001). The extracts were filtered using $0.45-\mu \mathrm{m}$ syringe cellulose filters $(25 \mathrm{~mm}$ diameter, Chromafil Xtra RC-45/25, Macherey-Nagel, Dublin, Ireland) and $50 \mu \mathrm{L}$ were injected onto the column to obtain the profiles. The separation of milk peptides was performed in the reversed-phase mode using an Agilent Zorbax 300SB C8 column (4.6 mm i.d. $\times 150 \mathrm{~mm}$, Agilent Technologies). The gradient elution and peak detection methodology was an adaption of the methodology of Rohm et al. (1996). The HPLC equipment used was an Agilent 1200s system (Agilent Technologies) with a quaternary pump and a multiwavelength detector.

\section{SDS-PAGE}

The individual proteins of the milk samples collected after 0,48 , and $72 \mathrm{~h}$ of storage were identified using pre-cast SDS-PAGE (Novex Technologies, Thermo Fisher Scientific, Waltham, MA) under reducing and nonreducing conditions. The inoculated milk samples were diluted in Milli-Q water to a protein concentration of approximately $5.7 \mu \mathrm{g} / \mu \mathrm{L}$, and then further diluted in SDS sample buffer [NuPAGE LDS Sample Buffer $(4 \times)$, Thermo Fisher Scientific)]. For reducing SDS-PAGE conditions, dithiothreitol [NuPAGE Sample Reducing Agent $(10 \times)$; concentration $=500 \mathrm{mmol} / \mathrm{L}$ (Thermo Fisher Scientific)] was added to the samples at a level of $10 \%$ (vol/vol) of the sample total volume. Samples were heated to $70^{\circ} \mathrm{C}$ for $10 \mathrm{~min}$, cooled, and loaded on $12 \%$ Bis-Tris SDS-PAGE gels $(10 \mu \mathrm{g} /$ well). A low-range protein ladder was also loaded on the gels $(10 \mu \mathrm{g} /$ well; Spectra Multicolor Low Range Protein Ladder, Thermo Fisher Scientific). The gels were run in SDS running buffer [NuPAGE MOPS SDS Running Buffer $(1 \times)$ ] at $200 \mathrm{~V}$ for $50 \mathrm{~min}$. After, the gels were stained for $24 \mathrm{~h}$ with Instant Blue Coomassie (Expedeon, Cambridge, UK).

\section{Statistical Analysis}

The results of the azocasein test for the pasteurized and nonpasteurized supernatants were statistically compared using the MIXED procedure (Student's ttest) in SAS 9.3 (SAS Institute Inc., Cary, NC).

Least squares means for the main effects of storage time and added protease activity, as well as the interaction between storage time and added protease activity, were calculated using the GLIMMIX procedure also in SAS 9.3. A repeated-measures ANOVA was used, where storage time is a within-subject factor and level of protease activity is a between-subject factor. The fixed effects included in each model were storage time $(0,48$, 
Table 1. Mean $( \pm \mathrm{SE})$ total bacterial count $(\mathrm{TBC})$ of control $(\mathrm{CON})$ and negative control (P10 neg) milk samples, as well as samples inoculated with $0.15,0.60$, and $1.50 \mathrm{U} / \mathrm{L}$ protease (treatments $\mathrm{P} 1, \mathrm{P} 4$, and $\mathrm{P} 10$, respectively), stored for up to $72 \mathrm{~h}$

\begin{tabular}{llccccc}
\hline & \multicolumn{5}{c}{ Protease activity } \\
\cline { 2 - 5 } $\begin{array}{l}\text { TBC } \\
\left(\log _{10} \mathrm{cfu} / \mathrm{mL}\right)\end{array}$ & $\mathrm{CON}$ & $\mathrm{P} 10 \mathrm{neg}$ & $\mathrm{P} 1$ & $\mathrm{P} 4$ & $\mathrm{P} 10$ & \multirow{2}{*}{ SE } \\
\hline $0 \mathrm{~h}$ & $3.11^{\mathrm{A}}$ & $3.22^{\mathrm{A}}$ & $4.14^{\mathrm{A}}$ & $4.46^{\mathrm{A}}$ & $4.77^{\mathrm{A}}$ & 0.24 \\
$48 \mathrm{~h}$ & $3.96^{\mathrm{AB}}$ & $4.26^{\mathrm{A}}$ & $5.45^{\mathrm{A}}$ & $6.00^{\mathrm{B}}$ & $6.00^{\mathrm{B}}$ & 0.24 \\
$72 \mathrm{~h}$ & $5.33^{\mathrm{B}}$ & $5.30^{\mathrm{B}}$ & $8.00^{\mathrm{B}}$ & $8.00^{\mathrm{C}}$ & $8.00^{\mathrm{C}}$ & 0.24 \\
\hline
\end{tabular}

${ }^{\mathrm{A}-\mathrm{C}}$ Values within a column not sharing common superscripts differ significantly $(P<0.05)$.

and $72 \mathrm{~h}$ ) and added protease activity (CON, P10 neg, $\mathrm{P} 1, \mathrm{P} 4$, and P10). The inoculated milk volumes within trial week were considered the experimental unit. The response variables were $\mathrm{pH}$; TBC; $\mathrm{RCT}, \mathrm{k}_{20}$, and $\mathrm{a}_{30}$; and $\kappa-\mathrm{CN}, \alpha_{\mathrm{S}_{1}} \mathrm{CN}, \alpha_{\mathrm{S} 2}-\mathrm{CN}, \beta-\mathrm{CN}, \alpha-\mathrm{LA}, \beta-\mathrm{LG} \mathrm{A}$, $\beta-\mathrm{LG} \mathrm{B}$, and total casein. Residual checks were made to ensure that the assumptions of the analysis were met. The Tukey test (at 5\% error probability) was used to compare the means for all variables.

\section{RESULTS}

\section{Total Bacterial Count}

The TBC of milk samples from different treatments and stored for up to $72 \mathrm{~h}$ are shown in Table 1. The TBC of the samples significantly increased with level of protease activity $(P<0.0001)$ in the milk samples and over storage time $(P<0.0001$; Table 1$)$. The interaction between storage time and added protease activity did not affect TBC $(P>0.05)$.

\section{Measurements of $\mathrm{pH}$ in Milk}

Protease activity did not affect the $\mathrm{pH}$ of the samples $(P=0.52)$. The mean $( \pm \mathrm{SE}) \mathrm{pH}$ measured in CON, $\mathrm{P} 10$ neg, $\mathrm{P} 1, \mathrm{P} 4$, and $\mathrm{P} 10$ samples were $6.51,6.53,6.53$, 6.54 , and $6.53 \pm 0.01$, respectively. Storage time also did not affect $\mathrm{pH}(P<0.0001)$, nor did the interaction between added protease activity and storage time $(P=$ 0.01 ). We did not observe decreases in $\mathrm{pH}$ over storage time, except in P10 samples. At 0,48 , and $72 \mathrm{~h}$ the $\mathrm{pH}$ measured in P10 samples were $6.58,6.55$, and 6.47 at 0 , 48 , and $72 \mathrm{~h}$, respectively $(P=0.001)$.

In addition, the mean $( \pm \mathrm{SE})$ fat $(3.44 \pm 0.30 \%)$ and protein $(3.58 \pm 0.06 \%)$ contents did not differ between treatments and during storage of milk $(P>0.05$; data not shown).

\section{Azocasein Assay and Protease Activity}

The mean $( \pm \mathrm{SE})$ result obtained for the supernatant samples that were not pasteurized was $0.547 \pm 0.109$ $\mathrm{nm}$. Based on this results, the mean $( \pm \mathrm{SE})$ protease activity calculated in the supernatant was $0.030 \pm 0.006$ $\mathrm{U} / \mathrm{mL} \cdot \mathrm{min}$. Also, the result obtained for nonpasteurized samples did not differ from the results obtained for the samples that were pasteurized $(0.535 \pm 0.114 \mathrm{~nm}$; $P>0.05)$.

\section{Proteolysis}

Casein Fractions. The significance of the main effects of storage time, added protease activity, and interaction between added protease activity and storage time on the concentration of caseins and major whey proteins of milk are shown in Table 2. The concentrations of those proteins measured in the milk samples from the different treatments stored for up to $72 \mathrm{~h}$ are also shown in Table 2.

Storage time affected the concentrations of $\alpha_{\mathrm{S}_{2}} \mathrm{CN}$ and $\beta$-CN. Protease activity and interaction between protease activity and storage time affected the concentrations of all caseins (Table 2).

Storage time affected the mean concentrations of $\alpha$-LA, added protease activity affected the mean concentrations of $\beta$-LG $\mathrm{A}$ and the interaction between those factors affected mean concentrations of $\beta-\mathrm{LG}$ B.

The casein chromatograms of the CON, P10 neg, $\mathrm{P} 1, \mathrm{P} 4$, and $\mathrm{P} 10$ samples, stored for up to $72 \mathrm{~h}$, are shown in Figure 3. The chromatograms of CON and P10 neg samples are similar and indicated low levels of proteolysis over storage. In relation to the inoculated samples, the levels of proteolysis increased with the activity of protease over storage time. The chromatograms indicated that $\kappa-\mathrm{CN}$ and $\beta-\mathrm{CN}$ were the main proteins hydrolyzed by the protease over time. We also observed small decreases in $\alpha_{\mathrm{S1}^{-}} \mathrm{CN}$ peaks with increasing added protease activity. In P10 samples, decreases in the concentrations of $\alpha_{\mathrm{S}^{-}} \mathrm{CN}$ and $\alpha_{\mathrm{S}^{2}} \mathrm{CN}$ after $48 \mathrm{~h}$ and decreases in the concentrations of $\beta-\mathrm{LG} \mathrm{A}$ and $\mathrm{B}$ after $72 \mathrm{~h}$ were greater compared with other samples (Table 2).

Peptide Profiles. The peptide profiles of CON, P10 neg, P1, P4, and P10 samples, stored for up to $72 \mathrm{~h}$ 
at $4^{\circ} \mathrm{C}$, are shown in Figure 4 . The peptide profiles of the CON and P10 neg samples were similar and low levels of proteolysis were observed. Over storage time, the hydrolysis of proteins in milk increased with added protease activity.

$S D S-P A G E$. Nonreducing and reducing SDS-PAGE electrophoretograms of all milk samples stored for up to $72 \mathrm{~h}$ are shown in Figures $5 \mathrm{~A}$ and $5 \mathrm{~B}$, respectively.

The electrophoretograms of the CON (lane 1) and P10 neg (lane 5) samples were similar and no apparent indication of proteolysis was observed. In contrast, the electrophoretograms of $\mathrm{P} 1, \mathrm{P} 4$, and $\mathrm{P} 10$ samples indicated that the protease was active mainly on $\kappa-\mathrm{CN}$ and $\beta-\mathrm{CN}$, bands for which became less intense and decreased in size over time. In addition, we noted a small decrease in bands corresponding to $\alpha_{\mathrm{S1}}-\mathrm{CN}$ with increasing level of protease activity. The decrease was more noticeable in $\mathrm{P} 10$ samples.

The intensity of the peptide bands from 10 to 25 $\mathrm{kDa}$, which are products of the hydrolysis of caseins, increased with level of protease activity. We observed those bands in samples tested after inoculation $(0 \mathrm{~h}$ of storage), indicating that the protease is highly active in milk. Also, a peptide band around $14 \mathrm{kDa}$ (above $\alpha$-LA) was observed in lanes corresponding to P1, P4, and P10 samples (lanes 2, 3, and 4, respectively) and its intensity increased with level of protease activity and storage time.

Rennet Coagulation Properties. The significance of the main effects of storage time, added protease ac- tivity, and interaction between added protease activity and storage time on the rennet coagulation properties of milk are shown in Table 3 . The values for RCT, $\mathrm{k}_{20}$, and $\mathrm{a}_{30}$ obtained for the milk samples from the different treatments, stored for up to $72 \mathrm{~h}$, are shown in Table 4. It was not possible to assess the rennet coagulation properties of the P10 milk samples after $48 \mathrm{~h}$, as those samples did not form a coagulum after rennet addition.

Rennet coagulation time decreased significantly with increasing levels of protease activity (CON, P10 neg, $\mathrm{P} 1$, and P4: $21.54,19.63,16.64$, and $16.81 \pm 1.16 \mathrm{~min}$, respectively; $P<0.05)$. Over $72 \mathrm{~h}$, we observed a decrease in RCT when testing P1 samples. The results also indicated that RCT may tend to increase over time for P4 samples.

The interaction between level of protease activity and storage time affected $\mathrm{a}_{30}(\mathrm{~mm})(P=0.002)$. Over $72 \mathrm{~h}$, $\mathrm{a}_{30}$ did not vary significantly for CON and P10 neg samples (Table 4). The variations in $\mathrm{a}_{30}$ measured in $\mathrm{P} 1$ samples were also not significant over $72 \mathrm{~h}$; however, we observed an increase in that value after $48 \mathrm{~h}$ of storage. In relation to $\mathrm{P} 4$ samples, $\mathrm{a}_{30}$ decreased significantly after $48 \mathrm{~h}(P=0.001$; Table 4$)$.

It was not possible to measure $\mathrm{k}_{20}$ value in $\mathrm{P} 4$ and P10 samples after 72 and $48 \mathrm{~h}$, respectively, as those samples did not reach a curd firmness of $20 \mathrm{~mm}$. Consequently, the data set obtained at 0 and $48 \mathrm{~h}$ was separated from the data obtained after $72 \mathrm{~h}$ for statistical analysis. After $48 \mathrm{~h}$, the $\mathrm{k}_{20}$ measured for CON, P10 neg, P1, and P4 samples was not affected by storage

Table 2. Mean $( \pm \mathrm{SE})$ contents of casein fractions $(\mathrm{mg} / \mathrm{mL})$ in control $(\mathrm{CON})$ and negative control $(\mathrm{P} 10$ neg) milk samples and samples inoculated with $0.15,0.60$, and $1.50 \mathrm{U} / \mathrm{L}$ (treatments $\mathrm{P} 1, \mathrm{P} 4$, and P10, respectively), stored for up to $72 \mathrm{~h}$, and significance of the main effects of protease activity, storage time, and the interaction between protease activity and storage time on those contents

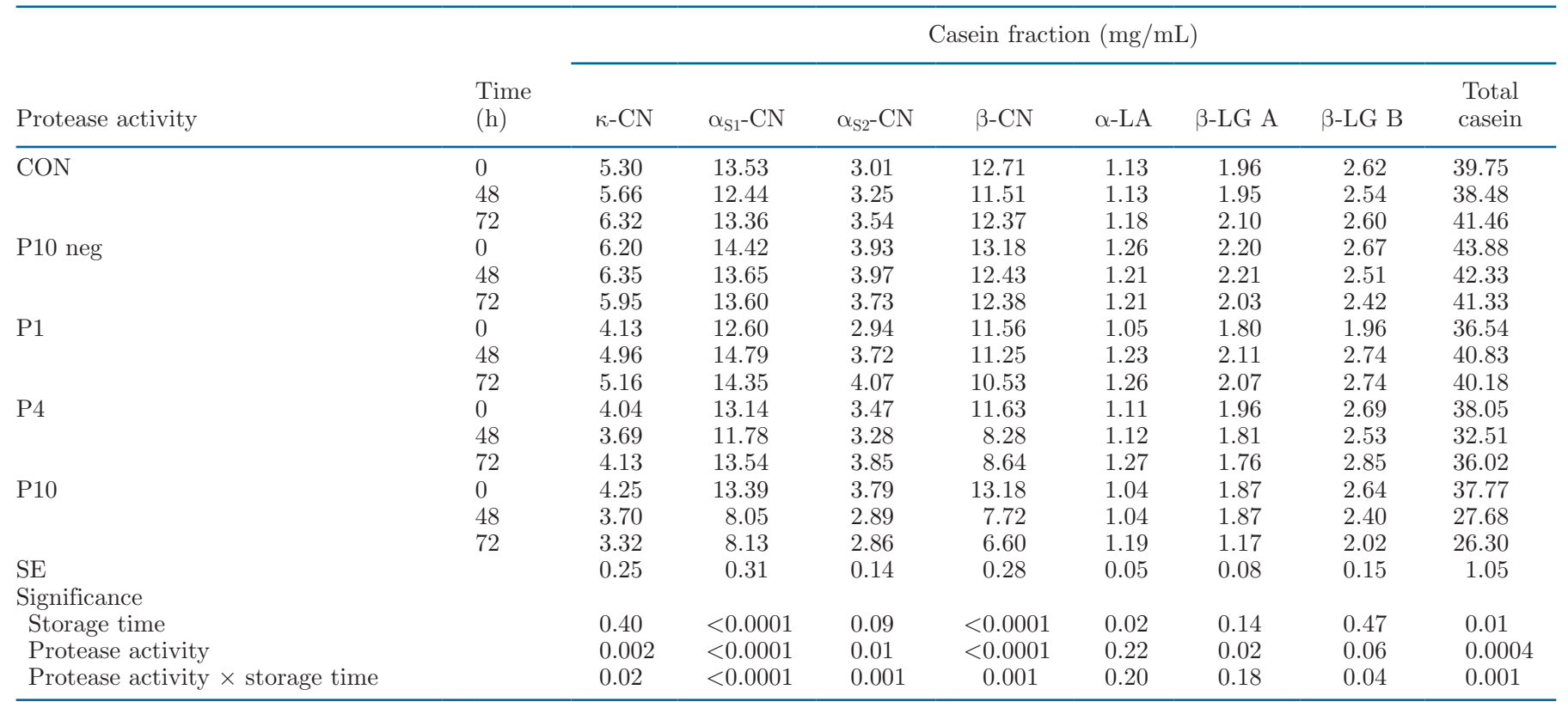



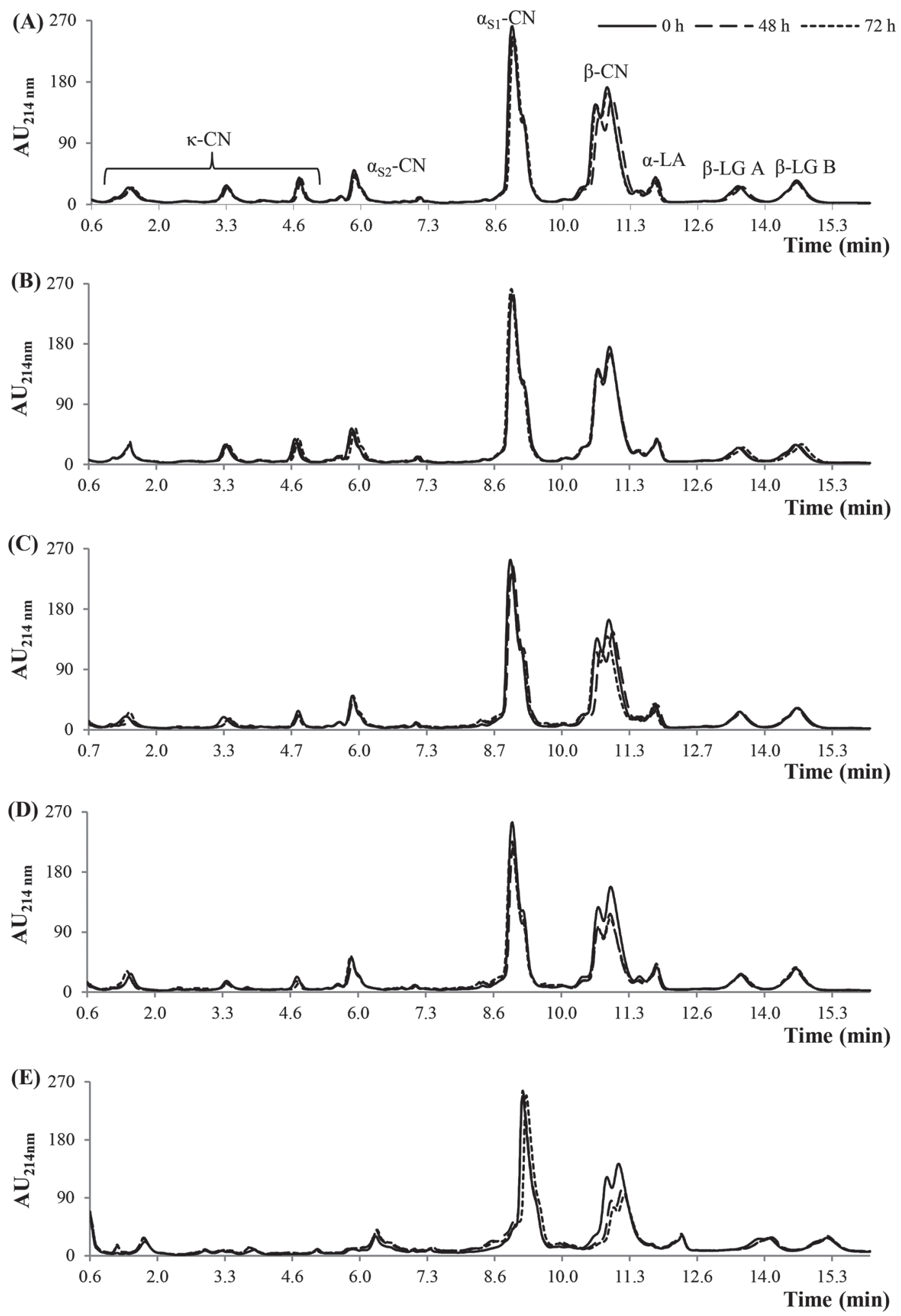

Figure 3. Separation of bovine milk caseins by reversed-phase HPLC (measured in absorbance units, AU). Chromatograms of (A) control and (B) negative control samples and samples inoculated with (C) 0.15 , (D) 0.60 , and (E) $1.50 \mathrm{U} / \mathrm{L}$ stored for up to $72 \mathrm{~h}$ are shown. 

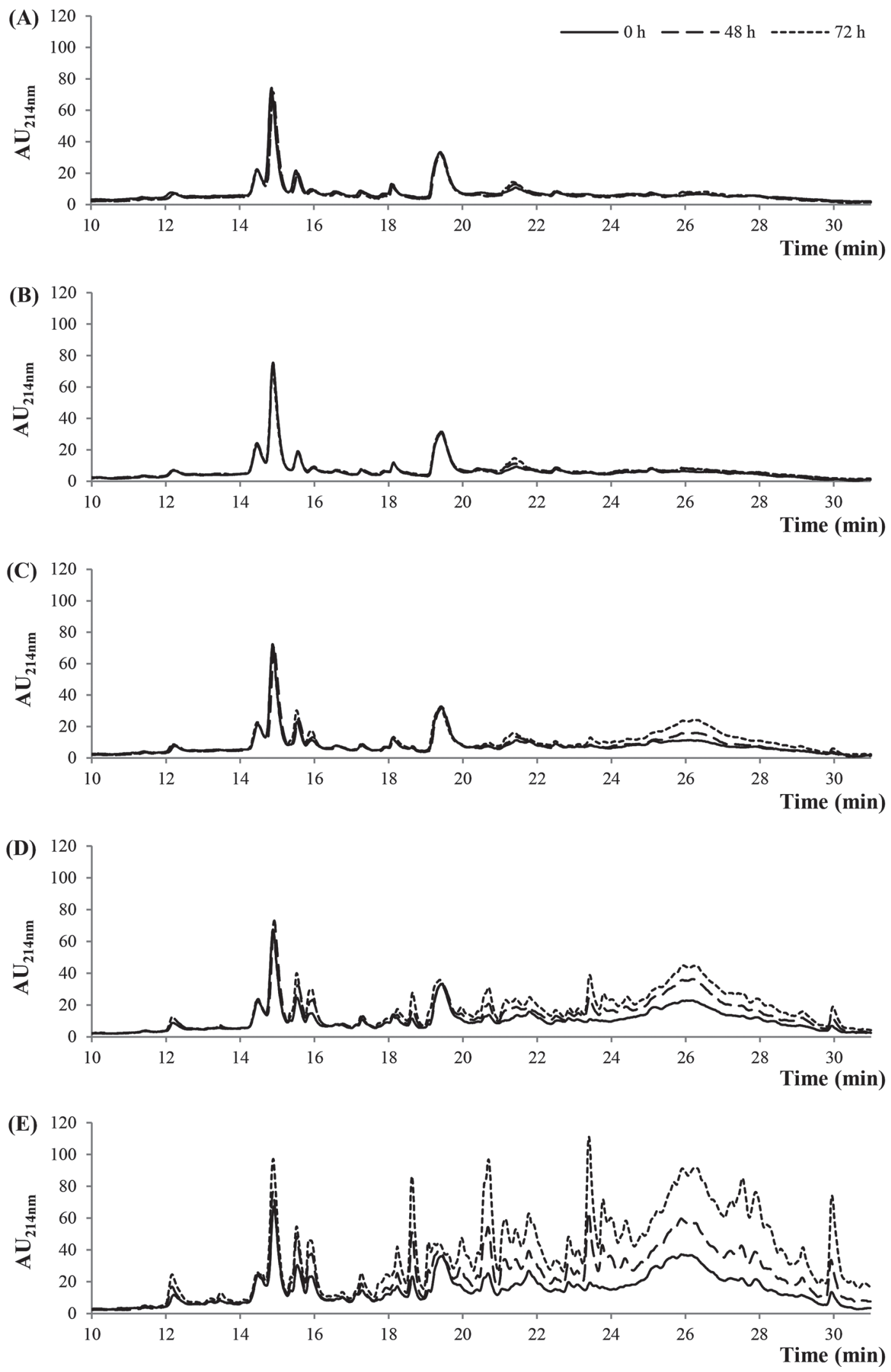

Figure 4. Separation of bovine milk peptides by reversed-phase HPLC (measured in absorbance units, AU). Chromatograms of (A) control and (B) negative control samples and samples inoculated with (C) 0.15 , (D) 0.60, and (E) $1.50 \mathrm{U} / \mathrm{L}$ stored for up to $72 \mathrm{~h}$ are shown. 
time $(P=0.56)$, added protease activity $(P=0.32)$, or interaction between those effects $(P=0.09)$. The CON, P10 neg, and P1 samples reached a curd firmness of 20 $\mathrm{mm}$ after $72 \mathrm{~h}$, and the $\mathrm{k}_{20}$ for those samples did not differ $(P=0.84)$.

\section{DISCUSSION}

According to the azocasein test, the strain of $P$. fluorescens (ATCC 17556) produced active proteases when incubated at $10^{\circ} \mathrm{C}$. This result is in accordance with

(A) Nonreducing
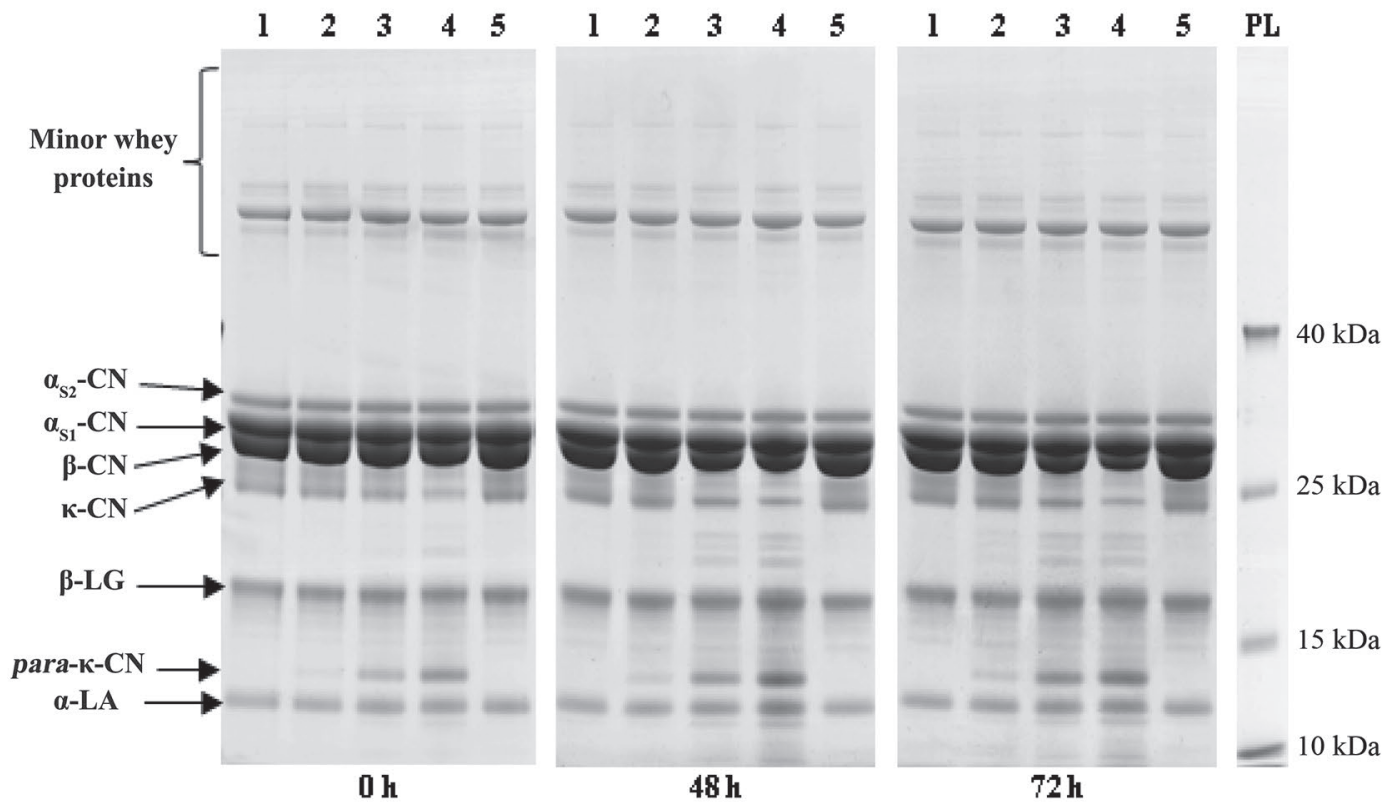

\section{(B) Reducing}
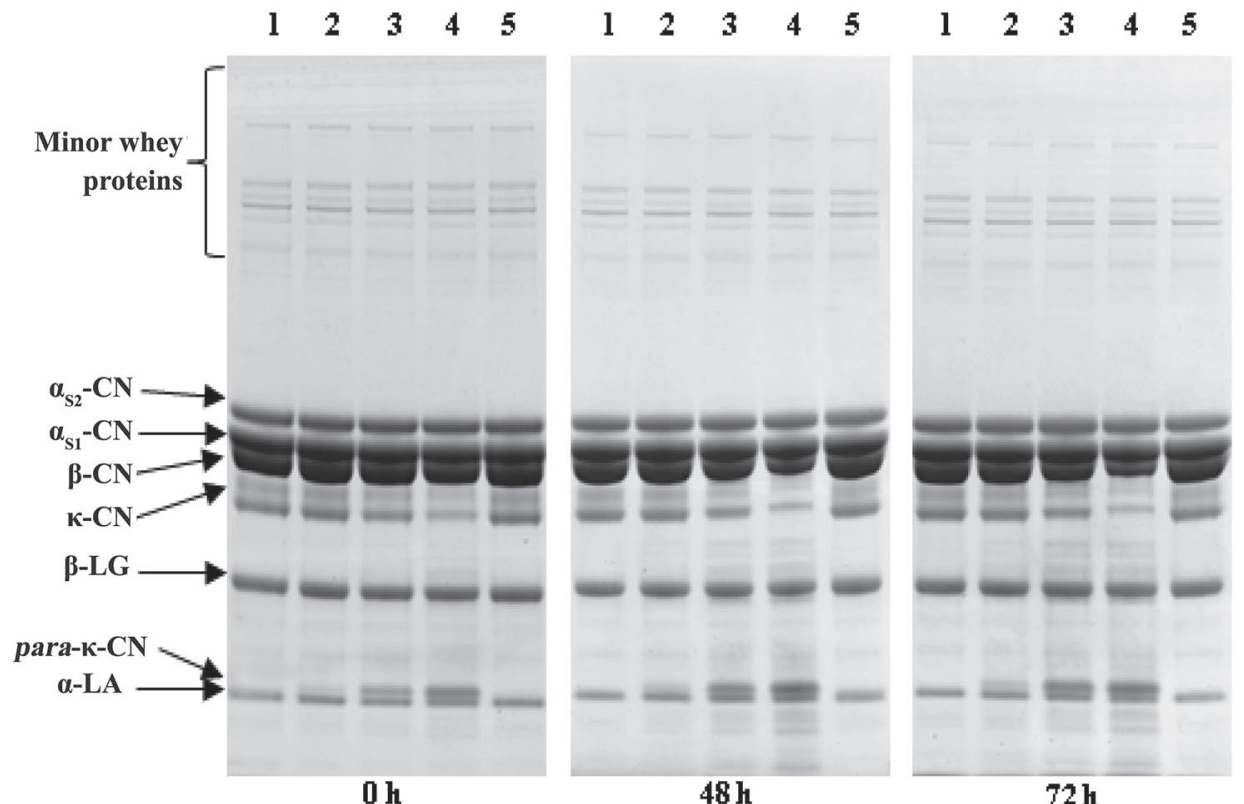

PL

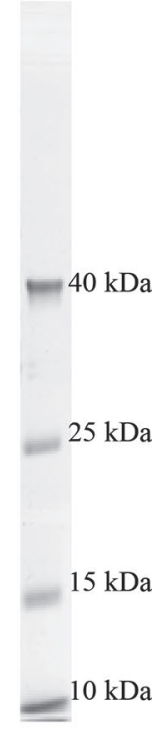

Figure 5. Sodium dodecyl sulfate-PAGE electrophoretogram of milk samples stored for up to $72 \mathrm{~h}$ under (A) nonreducing and (B) reducing conditions. Lane 1 corresponds to the control samples, and lanes 2 to 5 correspond to samples inoculated with 0.15 , 0.60, and $1.50 \mathrm{U} / \mathrm{L}$, and negative control, respectively. Lane PL corresponds to a low-range protein ladder. 
the study from Marchand et al. (2009), in which the same strain presented proteolytic activity at 7,22 , and $30^{\circ} \mathrm{C}$. In relation to the level of protease activity, Liao and McCallus (1998) cultured P. fluorescens CY091, centrifuged the medium, and obtained a protease activity varying from 5 to $8 \mathrm{U} / \mathrm{mL}$ in the supernatant. Those results differ from the activity obtained in this study, indicating that other strains may produce proteases with higher levels of activity. The production of protease could depend on several factors, such as bacterial strain, culture media, time, and temperature of incubation (McKellar, 1982).

The protease produced was thermoresistant, as its activity was maintained after pasteurization and therefore it would remain active during cheese manufacture. In addition, it is now widely shown that multiple Pseudomonas strains produce heat-resistant proteases (Bagliniere et al., 2013; Machado et al., 2017; Marchand et al., 2017).

The difference in $\mathrm{TBC}$ and bacterial growth rate between noninoculated samples (CON and P10 neg) and inoculated samples (P1, P4, and P10) over storage time at $4^{\circ} \mathrm{C}$ could be due to the presence of $P$. fluorescens cells in the supernatant used for inoculation. As the amount of supernatant added increased according to the aimed protease activity, the levels of TBC and bacterial growth rate also increased. The strains of $P$. fluorescens probably contributed to the increase in TBC because this strain can grow at temperatures up to $30^{\circ} \mathrm{C}$, which is close to the incubation temperature applied to measure mesophilic bacterial numbers $\left(32^{\circ} \mathrm{C}\right.$; Marchand et al., 2009).

After $72 \mathrm{~h}$, the $\mathrm{pH}$ of $\mathrm{P} 10$ samples decreased significantly, which could be due to the high levels of bacteria in those samples. The high bacterial activity could have increased the acidity of milk with the conversion of lactose into lactic acid. The decrease in $\mathrm{pH}$ could have potentially affected the structure of the coagulum of P10 milk samples after $48 \mathrm{~h}$, as the acidity could have

Table 3. The significance of the main effects of protease activity, storage time, and the interaction between protease activity and storage time on the rennet coagulation time (RCT, min) and curd firmness at $30 \min \left(\mathrm{a}_{30}, \mathrm{~mm}\right)$

\begin{tabular}{lccc}
\hline & \multicolumn{3}{c}{ Significance } \\
\cline { 2 - 4 } $\begin{array}{l}\text { Rennet } \\
\text { coagulation } \\
\text { properties }^{1}\end{array}$ & $\begin{array}{c}\text { Storage } \\
\text { time }\end{array}$ & $\begin{array}{c}\text { Protease } \\
\text { activity }\end{array}$ & $\begin{array}{c}\text { Protease activity } \\
\times \text { storage time }\end{array}$ \\
\hline $\mathrm{RCT}$ & 0.06 & 0.02 & 0.21 \\
$\mathrm{a}_{30}$ & 0.06 & 0.08 & 0.002 \\
\hline
\end{tabular}

${ }^{1}$ The significance levels obtained for $\mathrm{k}_{20}$ measurements were not included in this table as those measurements were separated in 2 groups (group 1: data obtained at 0 and $48 \mathrm{~h}$; group 2: data obtained only at $72 \mathrm{~h}$ ) for the statistical analysis, differently than for other measurements.

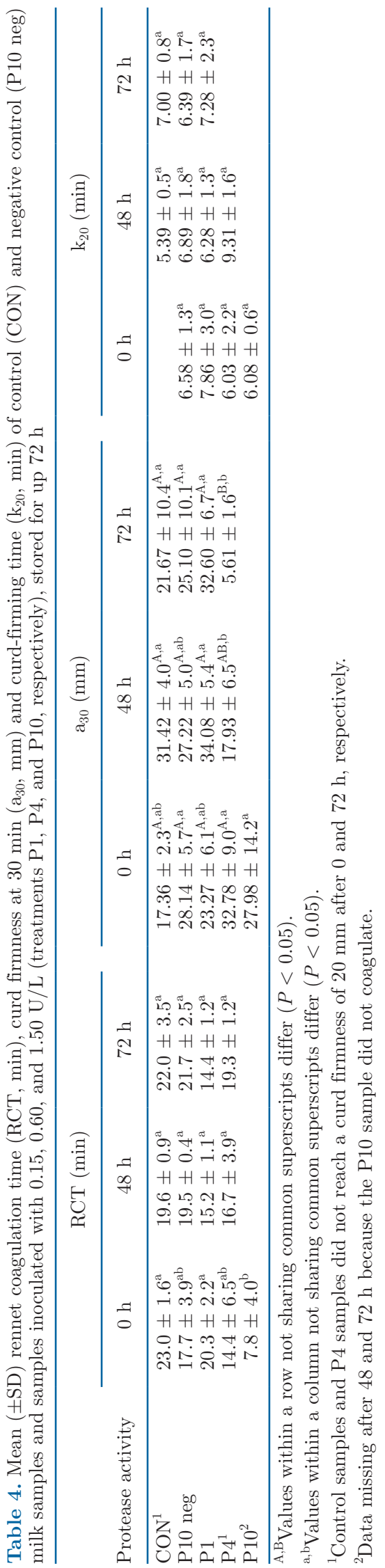


influenced the net charge and interaction of the casein micelles (Fox et al., 2017).

The similarity between the results obtained for CON and P10 neg samples, as well as how they differed from the results obtained for the inoculated samples, indicated that the methods of production and extraction of proteases were effective and that the protease was active in milk.

The casein concentrations (Table 2), as well as the results from the chromatograms (Figures 3 and 4) and electrophoretograms (Figure 5), indicated an increase in proteolysis levels with added protease activity over storage time. The protease tested preferably hydrolyzed $\kappa-\mathrm{CN}$ and $\beta-\mathrm{CN}$, whereas the rate of hydrolysis of $\alpha_{S}-\mathrm{CN}$ increased with level of protease activity. The breakdown of $\alpha_{S^{-}} \mathrm{CN}$ and major whey proteins was more noticeable when the level of protease activity was increased to $1.50 \mathrm{U} / \mathrm{L}$ (treatment P10, Figures 3 and 5; Table 2). Similar results were observed by Zhang et al. (2015) when investigating the degradation on milk proteins by a thermoresistant protease produced by $P$. fluorescens BJ-10.

Statistical analysis indicated that $\alpha-\mathrm{LA}$ and $\beta-\mathrm{LG}$ $B$ levels were affected by storage time and interaction between added protease activity and storage time, respectively. However, we observed no trends over time for the concentrations on those proteins and variations were minimal (Table 2). We also observed small variations in the concentrations of whey proteins in the chromatograms (Figure 3). The only trend we observed was the decrease in the whey protein peaks when the protease activity was $1.50 \mathrm{U} / \mathrm{L}$ (treatment P10).

The hydrolysis of the caseins affected the rennet coagulation properties of the milk from different treatments. Overall, the increase in the level of protease activity resulted in a decrease in $\mathrm{RCT}$. At $0 \mathrm{~h}$, we observed that trend, which could be linked to the hydrolysis of $\kappa-\mathrm{CN}$, an important casein for the coagulation of milk during cheesemaking. During coagulation, the $\mathrm{Phe}_{105}-\mathrm{Met}_{106}$ bond of $\kappa-\mathrm{CN}$ is hydrolyzed and the N-terminal that remains bound in the casein network is called para- $\kappa-$ CN. Due to changes in charges, the para-CN micelles are then able to aggregate in the presence of calcium ions (Fox et al., 2017). In the electrophoretograms (Figure 5), we observed a peptide band around $14 \mathrm{kDa}$ (above $\alpha-\mathrm{LA}$ ) in lanes corresponding to P1, P4, and P10 samples (2, 3, and 4, respectively) and its intensity increased with level of added protease activity and storage time. Timotijevic et al. (2006) obtained a similar result when testing different concentrations of rennet, and the authors identified that band as corresponding

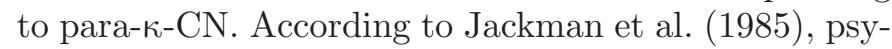
chrotrophic bacterial proteases include endopeptidases capable of hydrolyzing the phenylalanine-methionine bond of $\kappa-\mathrm{CN}$ in a similar manner to rennet. Therefore, the increase in added protease activity could have resulted in increasing hydrolysis rates of $\kappa-\mathrm{CN}$ into para$\kappa-\mathrm{CN}$, and consequently decreased RCT in inoculated milk samples.

After $48 \mathrm{~h}$, the RCT of $\mathrm{P} 1$ samples continued to decrease over storage time. In contrast, the RCT of P4 samples tended to increase over time, whereas P10 samples did not coagulate after $48 \mathrm{~h}$ (Table 4). In addition, the firmness $\left(a_{30}\right)$ of the coagulum formed when testing P1 samples increased over time, whereas the firmness of the coagulum of $\mathrm{P} 4$ samples significantly decreased over time $(P=0.01)$. The increase in RCT is potentially due to the enzymatic degradation of caseins. The $\alpha_{S}-\mathrm{CN}$ and $\beta$-CN constitute the basic microstructure of the curd, and reduced levels of those caseins results in slow curd formation and a soft coagulum as observed. Protease activity can affect the caseins to such an extent that coagulation of milk does not occur (St-Gelais and Hache, 2005; Amenu and Deeth, 2007), as observed in P10 samples. The proteolysis of caseins could result in curd shattering, high losses of fat in the whey, and reduced cheese yields (Fox et al., 2017). In relation to $\mathrm{P} 1$ samples, the rate of hydrolysis of $\alpha_{\mathrm{S}^{-}} \mathrm{CN}$ and $\beta$-CN was lower and therefore the structure of the casein micelles was less affected (Lu et al., 2017). Consequently, the coagulum produced was firmer compared with other inoculated samples. The firmness measured in those samples was also higher than the firmness of control samples, possibly due to the higher rate at which $\kappa-\mathrm{CN}$ was hydrolyzed into para- $\kappa-\mathrm{CN}$.

Finally, the inoculated samples had a similar TBC after 48 and $72 \mathrm{~h}$ of storage and still had different results in relation to proteolysis levels. Therefore, those results were mainly due to the protease activity added and not the bacterial count.

\section{CONCLUSIONS}

This study demonstrated that the protease produced by the psychrotrophic bacteria tested was thermoresistant and can affect the cheesemaking properties of milk. The rennet coagulation time and curd firmness were affected over storage time, as the protease was mainly active on essential caseins for the formation and structure of the coagulum ( $\kappa-\mathrm{CN}$ and $\beta-\mathrm{CN}$, respectively). The results indicated that certain levels of the protease tested can accelerate the coagulation of milk and produce a firmer coagulum, but increases in the level of protease-derived activity can result in a softer coagulum or a case where the coagulation of milk is not possible, due to extensive hydrolysis of $\alpha_{\mathrm{S}^{-}} \mathrm{CN}$ and major whey proteins. Both situations may be undesirable in an industrial cheesemaking setting, as consistency 
is required during production to obtain products with the same quality parameters. Therefore, this study highlighted the importance of controlling initial levels of psychrotrophs in milk, as the activity of their protease could affect the processability of milk over storage time. Further studies are necessary to determine the effect of those proteases on the manufacture and quality of cheese in an industrial scale. Additionally, as milk has a complex microbiota, it would be relevant to characterize other psychrotrophic bacterial proteases to determine their resistance to heat treatment and activity in milk.

\section{ACKNOWLEDGMENTS}

The authors acknowledge Jim Grant (Teagasc Ashtown, Dublin, Ireland) for guidance on the statistical analysis and Bernard Corrigan (Teagasc Food Research Centre, Fermoy, Co. Cork, Ireland) for guidance on using the HPLC. This research was funded by the Walsh Fellowship Program and Dairy Levy project (6643, Teagasc, Oak Park, Carlow, Co. Carlow, Ireland). The authors have not stated any conflicts of interest.

\section{REFERENCES}

Amenu, B., and H. C. Deeth. 2007. The impact of milk composition on cheddar cheese manufacture. Aust. J. Dairy Technol. 62:171-184.

Andreani, N. A., L. Carraro, L. Fasolato, S. Balzan, R. Lucchini, E. Novelli, and B. Cardazzo. 2016. Characterisation of the thermostable protease AprX in strains of Pseudomonas fluorescens and impact on the shelf-life of dairy products: Preliminary results. Ital. J. Food Saf. 5:6175. https://doi.org/10.4081/ijfs.2016.6175.

Bagliniere, F., A. Mateos, G. Tanguy, J. Jardin, V. Briard-Bion, F. Rousseau, B. Robert, E. Beaucher, J. L. Gaillard, C. Amiel, G. Humbert, A. Dary, and F. Gaucheron. 2013. Proteolysis of ultrahigh temperature-treated casein micelles by AprX enzyme from Pseudomonas fluorescens $F$ induces their destabilisation. Int. Dairy J. 31:55-61. https://doi.org/10.1016/j.idairyj.2013.02.011.

Baur, C., M. Krewinkel, B. Kranz, M. von Neubeck, M. Wenning, S. Scherer, M. Stoeckel, J. Hinrichs, T. Stressler, and L. Fischer. 2015. Quantification of the proteolytic and lipolytic activity of microorganisms isolated from raw milk. Int. Dairy J. 49:23-29. https: //doi.org/10.1016/j.idairyj.2015.04.005.

Boulares, M., M. Mankai, and M. Hassouna. 2011. Effect of activating lacto-peroxidase system in cheese milk on the quality of SaintPaulin cheese. Int. J. Dairy Technol. 64:75-83. https://doi.org/10 $.1111 / \mathrm{j} .1471-0307.2010 .00646 . x$.

Cousin, M. A. 1982. Presence and activity of psychrotrophic microorganisms in milk and dairy products: A review. J. Food Prot. 45:172-207. https://doi.org/10.4315/0362-028X-45.2.172.

Decimo, M., S. Morandi, T. Silvetti, and M. Brasca. 2014. Characterization of gram-negative psychrotrophic bacteria isolated from Italian bulk tank milk. J. Food Sci. 79:M2081-M2090. https://doi .org/10.1111/1750-3841.12645.

Ercolini, D., F. Russo, I. Ferrocino, and F. Villani. 2009. Molecular identification of mesophilic and psychrotrophic bacteria from raw cow's milk. Food Microbiol. 26:228-231. https://doi.org/10.1016/ j.fm.2008.09.005.

Fox, P. F., T. P. Guinee, T. M. Cogan, and P. H. McSweeney. 2017. Fundamentals of Cheese Science. 2nd ed. Springer, New York, NY.
IDF. 2001. Milk: Determination of Nitrogen Content-Part 4: Block Digestion Method (Semi-micro Rapid Routine Method). Standard 20-4. International Dairy Federation (IDF), Brussels, Belgium.

Jackman, D. M., T. R. Patel, and N. F. Haard. 1985. Effect of heatstable proteases on the kinetic parameters of milk clotting by chymosin. J. Food Sci. 50:602-604. https://doi.org/10.1111/j.1365 $-2621.1985 . t b 13754 . x$.

Lafarge, V., J. C. Ogier, V. Girard, V. Maladen, J. Y. Leveau, A. Gruss, and A. Delacroix-Buchet. 2004. Raw cow milk bacterial population shifts attributable to refrigeration. Appl. Environ. Microbiol. 70:5644-5650. https://doi.org/10.1128/AEM.70.9.5644 -5650.2004 .

Laird, D. T., S. A. Gambrel-Lenarz, F. M. Scher, T. E. Graham, and R. Reddy. 2004. Microbiological Count Methods. Pages 153-186 in Standard Methods for the Examination of Dairy Products, 17th ed. H. M. Wehr and J. F. Frank, ed. American Public Health Association, Washington, DC.

Leighton, T. J., R. H. Doi, R. A. Warren, and R. A. Kelln. 1973. The relationship of serine protease activity to RNA polymerase modification and sporulation in Bacillus subtilis. J. Mol. Biol. 76:103122. https://doi.org/10.1016/0022-2836(73)90083-1.

Leitner, G., N. Silanikove, S. Jacobi, L. Weisblit, S. Bernstein, and U. Merin. 2008. The influence of storage on the farm and in dairy silos on milk quality for cheese production. Int. Dairy J. 18:109-113. https://doi.org/10.1016/j.idairyj.2007.09.001.

Liao, C. H., and D. E. McCallus. 1998. Biochemical and genetic characterization of an extracellular protease from Pseudomonas fluorescens CY091. Appl. Environ. Microbiol. 64:914-921. https://doi .org/10.1128/AEM.64.3.914-921.1998.

López-Fandiño, R., A. Olano, N. Corzo, and M. Ramos. 1993. Proteolysis during storage of UHT milk: Differences between whole and skim milk. J. Dairy Res. 60:339-347. https://doi.org/10.1017/ S0022029900027680.

Lu, Y., D. J. McMahon, and A. H. Vollmer. 2017. Investigating rennet coagulation properties of recombined highly concentrated micellar casein concentrate and cream for use in cheese making. J. Dairy Sci. 100:892-900. https://doi.org/10.3168/jds.2016-11648.

Machado, S. G., F. Baglinière, S. Marchand, E. Van Coillie, M. C. D. Vanetti, J. De Block, and M. Heyndrickx. 2017. The biodiversity of the microbiota producing heat-resistant enzymes responsible for spoilage in processed bovine milk and dairy products. Front. Microbiol. 8:302. https://doi.org/10.3389/fmicb.2017.00302.

Mankai, M., M. Boulares, O. Ben Moussa, R. Karoui, and M. Hassouna. 2012. The effect of refrigerated storage of raw milk on the physicochemical and microbiological quality of Tunisian semihard Gouda-type cheese during ripening. Int. J. Dairy Technol. 65:250259. https://doi.org/10.1111/j.1471-0307.2012.00822.x.

Marchand, S., B. Duquenne, M. Heyndrickx, K. Coudijzer, and J. De Block. 2017. Destabilization and off-flavors generated by Pseudomonas proteases during or after UHT-processing of milk. Int. J. Food Contam. 4:2. https://doi.org/10.1186/s40550-016-0047-1.

Marchand, S., G. Vandriesche, A. Coorevits, K. Coudijzer, V. De Jonghe, K. Dewettinck, P. De Vos, B. Devreese, M. Heyndrickx, and J. De Block. 2009. Heterogeneity of heat-resistant proteases from milk Pseudomonas species. Int. J. Food Microbiol. 133:68-77. https://doi.org/10.1016/j.ijfoodmicro.2009.04.027.

Martins, M. L., U. M. Pinto, K. Riedel, and M. C. D. Vanetti. 2015. Milk-deteriorating exoenzymes from Pseudomonas fluorescens 041 isolated from refrigerated raw milk. Braz. J. Microbiol. 46:207217. https://doi.org/10.1590/S1517-838246120130859.

McKellar, R. C. 1982. Factors influencing the production of extracellular proteinase by Pseudomonas fluorescens. J. Appl. Microbiol. 53:305-316. https://doi.org/10.1111/j.1365-2672.1982.tb01276.x.

McMahon, D. J., and R. J. Brown. 1982. Evaluation of formagraph for comparing rennet solutions. J. Dairy Sci. 65:1639-1642. https:// doi.org/10.3168/jds.S0022-0302(82)82390-4

Mounsey, J. S., and B. T. O'Kennedy. 2009. Stability of $\beta$-lactoglobulin/ micellar casein mixtures on heating in simulated milk ultrafiltrate at $\mathrm{pH}$ 6.0. Int. J. Dairy Technol. 62:493-499. https://doi.org/10 $.1111 / \mathrm{j} .1471-0307.2009 .00522 . x$. 
Muir, D. D. 1996. The shelf life of dairy products: II. Raw milk and fresh products. J. Soc. Dairy Technol. 49:44-48. https://doi.org/ 10.1111/j.1471-0307.1996.tb02487.x.

Paludetti, L. F., A. L. Kelly, B. O'Brien, K. Jordan, and D. Gleeson. 2018. The effect of different precooling rates and cold storage on milk microbiological quality and composition. J. Dairy Sci. 101:1921-1929. https://doi.org/10.3168/jds.2017-13668.

Ricciardi, A., A. Guidone, T. Zotta, A. Matera, S. Claps, and E. Parente. 2015. Evolution of microbial counts and chemical and physico-chemical parameters in high-moisture Mozzarella cheese during refrigerated storage. Lebensm. Wiss. Technol. 63:821-827. https://doi.org/10.1016/j.lwt.2015.04.008.

Rohm, H., D. Jaros, C. Rockenbauer, M. Riedler-Hellrigl, T. UniackeLowe, and P. F. Fox. 1996. Comparison of ethanol and trichloracetic acid fractionation for measurement of proteolysis in Emmental cheese. Int. Dairy J. 6:1069-1077. https://doi.org/10.1016/S0958 -6946(96)00021-0.

St-Gelais, D., and S. Hache. 2005. Effect of $\beta$-casein concentration in cheese milk on rennet coagulation properties, cheese composition and cheese ripening. Food Res. Int. 38:523-531. https://doi.org/10 .1016/j.foodres.2004.11.006.

Stoeckel, M., M. Lidolt, T. Stressler, L. Fischer, M. Wenning, and J. Hinrichs. 2016. Heat stability of indigenous milk plasmin and proteases from Pseudomonas: A challenge in the production of ultra- high temperature milk products. Int. Dairy J. 61:250-261. https:/ /doi.org/10.1016/j.idairyj.2016.06.009.

Timotijevic, G. S., S. R. Radovic, and V. R. Maksimovic. 2006. Aspartic proteinases from buckwheat (Fagopyrum esculentum moenchi) seeds-Purification and properties of the $47 \mathrm{kDa}$ enzyme. Arch. Biol. Sci. 58:171-177. https://doi.org/10.2298/abs0603171t.

Wehr, H. M., and J. F. Frank. 2004. Standard Methods for the Examination of Dairy Products. 17th ed. American Public Health Association, Washington, DC.

Zhang, C., E. Bijl, and K. Hettinga. 2018. Destabilization of UHT milk by protease AprX from Pseudomonas fluorescens and plasmin. Food Chem. 263:127-134. https://doi.org/10.1016/j.foodchem 2018.04.128.

Zhang, S., H. Li, H. Uluko, L. Liu, X. Pang, and J. Lv. 2015. Investigation of protease production by Pseudomonas fluorescens BJ10 and degradation on milk proteins. J. Food Process. Preserv. 39:2466-2472. https://doi.org/10.1111/jfpp.12496.

\section{ORCIDS}

Lizandra F. Paludetti ํ https://orcid.org/0000-0002-8672-4522

Alan L. Kelly @i https://orcid.org/0000-0003-2759-1587

David Gleeson ๑ https://orcid.org/0000-0003-3064-3632 